\title{
FAKTOR-FAKTOR YANG MEMENGARUHI PERILAKU KONSUMSI KOPI DI ERA PANDEMI COVID-19
}

\author{
Novie Nostalgia Adiwinata ${ }^{1^{*}}$, Ujang Sumarwan ${ }^{2}$, Megawati Simanjuntak ${ }^{2}$ \\ ${ }^{1}$ Sekolah Bisnis, IPB University, Bogor 16151, Indonesia \\ ${ }^{2}$ Departemen IImu Keluarga dan Konsumen, Fakultas Ekologi Manusia, \\ IPB University, Bogor 16680, Indonesia \\ ${ }^{*}$ E-mail: novnos244@gmail.com
}

\begin{abstract}
Abstrak
Pada masa pandemi Covid-19, terjadi perubahan gaya hidup masyarakat salah satunya pada pola perilaku konsumsi kopi. Tujuan dari penelitian ini adalah menganalisis perilaku konsumsi yang dipengaruhi oleh beberapa faktor yaitu perceived behavioral control, motivasi, dan gaya hidup dan merumuskan implikasi menajerial yang dapat digunakan oleh para produsen kopi untuk mampu memasarkan produknya pada masa pandemi Covid-19. Penelitian ini menggunakan desain cross-sectional study dengan pendekatan kuantitatif. Data diperoleh dengan menyebarkan kuesioner secara online menggunakan media sosial. Pada penelitian ini teknik yang digunakan untuk mengambil contoh adalah voluntary sampling sebanyak 200 responden. Metode analisis yang digunakan dalam penelitian ini yaitu Structural Equation Modeling (SEM). Hasil dari penelitian ini yaitu terdapat pengaruh positif signifikan antara motivasi dan gaya hidup terhadap perilaku konsumen. Tidak terdapat pengaruh signifikan antara perceived behavioral control terhadap perilaku konsumsi. Implikasi manajerial yang dapat digunakan oleh para produsen kopi adalah produsen selalu konsisten menjaga mutu produk, selalu menggunakan inovasi terbaru pada produk minuman kopi agar lebih bervariasi, dan meningkatkan promosi produknya dengan memanfaatkan media sosial atau acara atau promo.
\end{abstract}

Kata kunci: gaya hidup, kopi, motivasi, perceived behaviour control, perilaku konsumsi

\section{Factors Affecting Coffee Consumption Behavior in Covid-19 Era}

\begin{abstract}
During the Covid-19 pandemic, there were changes in people's lifestyles, one of which was the behavior pattern of coffee consumption. The purpose of this study is to analyze consumption behavior which is influenced by several factors, namely perceived behavioral control, motivation, and lifestyle and to formulate managerial implications that can be used by coffee producers to be able to market their products during the Covid-19 pandemic. This study used a cross-sectional study design with a quantitative approach. Data obtained by distributing questionnaires online using social media. In this study, the technique used to take samples was voluntary sampling of 200 respondents. The analytical method used in this research is Structural Equation Modeling (SEM). The result of this research is that there is a significant positive influence between motivation and lifestyle on consumer behavior. There is no significant effect between perceived behavioral control on consumption behavior. The managerial implication that can be used by coffee producers is that producers always consistently maintain product quality, always use the latest innovations in coffee beverage products to make it more varied, and increase product promotion by utilizing social media or events or promos.
\end{abstract}

Keywords: coffee, consumption behavior, life style, motivation, perceived behavior control

\section{PENDAHULUAN}

Bisnis coffee shop saat ini dinilai cukup kompetitif dan selalu berkembang seiring perubahan zaman dan gaya hidup masyarakat. Riset independen menunjukkan fakta bahwa jumlah kedai kopi hingga pada pertengahan 2019 melonjak lebih dari tiga kali lipat atau mencapai 2.950 gerai dibandingkan dengan tahun 2016 yang hanya berjumlah 1.000 gerai
(Toffin, 2019). Berdasarkan data, 74 persen masyarakat lebih memilih mengonsumsi kopi yang disajikan di kafe atau restoran dibanding membuat kopi sendiri di rumah (Statista, 2020). Adanya tren "nongkrong" di coffee shop dan strategi pemasaran yang agresif dari berbagai coffee shop membuat masyarakat terjebak dalam arus gaya hidup konsumtif (Bong, 2011; Demartoto, Kartono, \& Solikatun, 2015; Pandowo, Pangemanan, \& Sangian, 2020). 
Keputusan konsumen dalam membeli kopi pada dasarnya dapat dilihat dari motifnya yaitu ingin atau butuh minum kopi (Pangestu \& Suryoko, 2016). Selain motif adapun motivasi yang muncul untuk mengonsumsi kopi. Motivasi yang ada dalam diri konsumen tersebut mendorong untuk melakukan kegiatan agar tercapai suatu tujuan baik itu tujuan untuk memenuhi kebutuhan atau memenuhi kesenangan (Charumathi \& Varadaraj, 2019; Kim, Ozkara, \& Ozmen, 2017).

Beberapa literatur terkait motivasi menunjukkan bahwa pertimbangan nilai-nilai produk beserta fungsinya menjadi salah satu dorongan dalam melakukan pembelian atau sering disebut dengan motivasi utilitarian (Charumathi \& Varadaraj, 2019; Hanzaee \& Irani, 2011). Sementara itu, terdapat pula motivasi konsumen yang berhubungan dengan pemenuhan kebutuhan emosional atau yang disebut dengan motivasi hedonis yang menunjukkan bahwa konsumen melihat aspek yang berkenaan dengan kebutuhan emosional dalam pemilihan produk (Chang, Chen, \& Chen, 2017; Kim, Ozkara, \& Ozmen, 2017). Pengendalian terhadap perilaku pembelian yang disebut dengan perceived behavioral control. Perceived behavioral control tertuju pada seseorang yang mempunyai suatu keyakinan dalam perilaku yang dilakukannya (Ajzen, 1991). Adanya motivasi dan perceived behavioral control tersebut menjadi faktor yang dipertimbangkan konsumen sehingga dapat memengaruhi perilaku konsumen terhadap suatu produk (Khalikussabir, Mukorobin, \& Wahono, 2020; Pangestuti, Sunarti, \& Wijaya, 2018).

Perilaku konsumen juga dapat dipengaruhi oleh adanya tingkat ekonomi beserta gaya hidup konsumen. Semakin maju perekonomian konsumen maka gaya hidup konsumen juga akan semakin tinggi dan pembelian juga semakin meningkat (Bong, 2011). Pertumbuhan ekonomi Indonesia pada tahun 2020 awalnya diprediksi sebesar 5,3 persen namun angka tersebut berubah akibat dampak pandemi Covid-19 sehingga pertumbuhan ekonomi Indonesia tahun 2020 saat ini diprediksi berada di bawah 2 persen (Hadiwardoyo, 2020). Kopi bukanlah kebutuhan pokok konsumen namun mengonsumsi kopi dari coffee shop sudah menjadi gaya hidup yang melekat dalam aktivitas konsumen sehingga akan sulit untuk dilepaskan (Demartoto et al., 2015). Berdasarkan penelitian, di era pandemi Covid19 ini penjualan kopi instan di beberapa negara melonjak 30 persen dan konsumsi kopi di rumah meningkat 7,6 persen sedangkan permintaan kopi di restoran menurun 14 persen, hal tersebut diperkirakan terjadi juga di pasar Asia Tenggara (Nielsen, 2020).

Pada dasarnya, dalam mengonsumsi suatu produk konsumen akan memiliki dorongan dari dalam diri yang disebut dengan motivasi (Kanuk \& Schiffman, 2010). Dalam hal ini, seorang penikmat kopi yang terbiasa memiliki gaya hidup mengonsumsi kopi akan cenderung memiliki dorongan dalam diri untuk memenuhi kebutuhannya akan kopi dalam kondisi apapun. Di sisi lain, perceived behavioral control yang dimiliki oleh konsumen berhubungan dengan hambatan dan kemudahan yang dihadapinya. Pada era pandemi Covid-19, penyebaran virus tidak mudah untuk dikontrol dan vaksin untuk penanggulangannya pun sudah ada tetapi belum semua masyarakat mendapatkannya. Kondisi pandemi tersebut dapat menjadi hambatan bagi konsumen untuk memenuhi kebutuhannya akan produk minuman kopi. Berdasarkan pemaparan di atas, pandemi Covid-19 dapat memengaruhi pola konsumsi masyarakat salah satunya terhadap produk minuman kopi.

Penelitian perihal perceived behavioral control, motivasi, dan gaya hidup berpengaruh terhadap perilaku konsumsi masyarakat telah dilakukan oleh beberapa peneliti. Hasil penelitian menyatakan bahwa perceived behavioral control berpengaruh terhadap perilaku konsumsi makanan cepat saji (Andi, Haghi, \& Tonekaboni, 2018; Mirkarimi et al., 2016). Penelitian lainnya menemukan bahwa motivasi berpengaruh terhadap perilaku konsumsi (Kurniawati, Kohar, \& Syuhada, 2015; Praktiko \& Fatchurahman, 2012). Gaya hidup diketahui berpengaruh terhadap perilaku konsumsi (Budanti, 2017; Iskandar \& Rahmayanti, 2018). Namun, yang membedakan penelitian ini dengan penelitian sebelumnya ialah penelitian ini dilakukan pada masa pandemi Covid-19. Hal inilah yang menjadi alasan penelitian ini dilakukan perihal pola perilaku konsumsi produk minuman kopi berdasarkan motivasi, perceived behaviour control, dan gaya hidup, terutama di era pandemi Covid-19 ini. Berdasarkan uraian di atas, tujuan pada penelitian ini adalah menganalisis perceived behavioral control, motivasi, dan gaya hidup berpengaruh terhadap perilaku konsumsi serta merumuskan implikasi manajerial yang dapat digunakan oleh para produsen kopi untuk mampu memasarkan produknya. Berikut hipotesis yang digunakan dalam penelitian: 


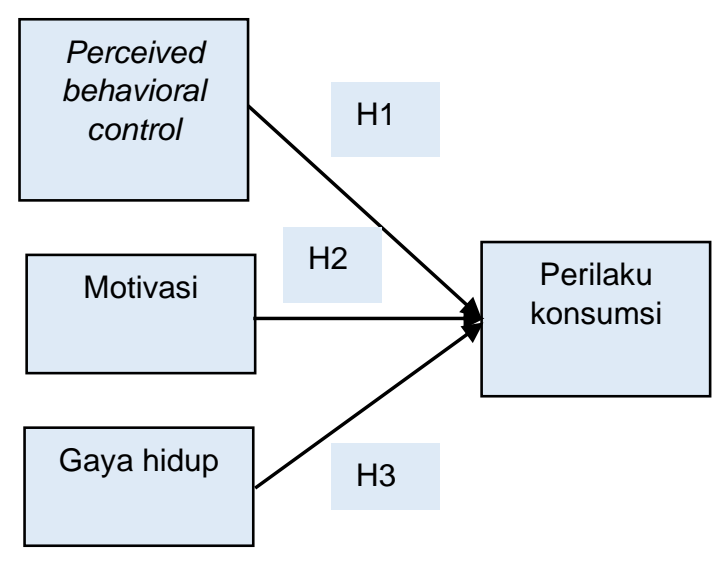

$\mathrm{H}_{1}:$ Perceived behavioral control berpengaruh
signifikan terhadap perilaku konsumsi
$\mathrm{H}_{2}:$ Motivasi berpengaruh signifikan terhadap
perilaku konsumsi
$\mathrm{H}_{3}:$ Gaya hidup berpengaruh signifikan
terhadap perilaku konsumsi

Gambar 1 Kerangka pemikiran konseptual

\section{METODE}

Desain penelitian ini yaitu cross-sectional survey. Penelitian ini membandingkan perilaku konsumsi kopi sebelum dan saat pandemi Covid-19. Penelitian ini dilaksanakan pada Oktober 2020 dan lokasi penelitian ini dilakukan di wilayah Jabodetabek. Penelitian ini menggunakan data primer dan sekunder. Kuesioner yang diambil secara online melalui tautan kuesioner menggunakan Google Form menjadi data primer. Data sekunder diperoleh dari bahan kepustakaan, artikel, dan media cetak serta literatur lainnya yang memiliki keterkaitan dengan topik. Penelitian ini menggunakan teknik pengambilan contoh voluntary sampling. Jumlah responden yang telah memenuhi screening adalah

200 responden. Responden penelitian ini dibatasi hanya konsumen yang pernah mengonsumsi produk minuman kopi minimal satu kali dalam kurung waktu enam bulan terakhir sejak Pandemi Covid-19 di Indonesia.

Variabel pada penelitian ini adalah perceived behavioral control (X1) yaitu suatu derajat atau persepsi dari tingkat kesulitan individu yang merasa bahwa tampil atau tidaknya suatu perilaku, pengalaman, dan estimasi untuk menjalankan sebuah perilaku tersebut (Maslichah, Samudra, \& Sudaryanti, 2020; Tawaqal, 2016). Perceived behavioral control mengacu pada keyakinan seseorang dan merasa mampu untuk menetapkan perilaku yang mereka sukai (Basri, Shabri, \& Wahyuni,
2016). Pengukuran variabel Perceived behavioral control terdiri dari 6 pernyataan dengan 2 indikator yaitu indikator kontrol keyakinan dan indikator kekuatan kepercayaan (Pathak \& Yadav, 2017). Seluruh variabel pada penelitian ini diukur menggunakan skala interval lima tingkatan untuk menyatakan jawaban responden yaitu sangat tidak setuju, tidak setuju, cukup setuju, setuju, dan sangat setuju. Uji reliabilitas merujuk pada uji konsistensi data yang diperoleh. $U j \mathrm{ji}$ ini diperlukan untuk mengukur tingkat kehandalan kuesioner dengan mengkaji nilai cronbach's alpha. Menurut Latan dan Ghozali (2012), variabel dinyatakan reliabel jika memiliki nilai cronbach's alpha $>0,6$. Secara keseluruhan variabel pada penelitian ini memiliki nilai $>0,6$ sehingga telah memenuhi syarat reliabilitas. Data pada penelitian ini diolah menggunakan Microsoft Excel 2010, SPSS 24, dan SmartPLS. Penelitian ini menggunakan analisis data dengan cara deskriptif. Analisis deskriptif bertujuan untuk melihat sebaran karakteristik responden.

Selanjutnya, motivasi (X2) yaitu suatu dorongan untuk melakukan tindakan memenuhi keinginan dan kebutuhan seseorang. Pengukuran variabel motivasi dilakukan menggunakan 8 pernyataan yang dibagi menjadi 2 indikator yaitu motivasi hedonis dan motivasi utilitarian. Motivasi hedonis adalah motivasi belanja yang dilakukan untuk memenuhi kepuasan emosional konsumen (Budiarti \& Puspita, 2016). Motivasi hedonis yaitu suatu motivasi pembelian dari dalam diri konsumen karena konsumen menyukainya, didorong dengan keinginan untuk mencapai suatu bentuk kesenangan, kebebasan, khayalan, serta pelarian diri dari masalah atau berdasarkan kebutuhan emosional konsumen (Bhatnagar \& Ghosh, 2004; Husna \& Lubis, 2019). Motivasi utilitarian merupakan sikap ketika berbelanja dan dipandang sebagai hal pengalaman positif bagi konsumen sehingga mereka bisa menikmati pengalaman emosional yang memuaskan (Purwanto \& Sukamdani, 2016). Dengan motivasi utilitarian, berbelanja dipandang sebagai pengalaman positif bagi konsumen sehingga mereka bisa menikmati pengalaman emosional memuaskan memilih suatu produk berdasarkan manfaat baik pada nilai efiseinsi dan prestasi (Ainiah, 2019; Hartuti, 2018).

Gaya hidup (X3) yaitu gambaran cara seseorang dalam berinteraksi dan dipengaruhi oleh faktor lingkungan di kehidupan masyarakat sehari-hari atau adanya interaksi sosial (Sahrazad, 2011; Siregar, 2015). Gaya hidup 
juga dipengaruhi oleh kebutuhan konsumen yang bervariasi yang mengubah pola gaya hidupnya (Wahyuningsih, 2015). Gaya hidup diukur berdasarkan jawaban responden terhadap

Kuesioner terdiri atas 16 pernyataan yang dibagi dalam delapan indikator, yaitu innovators (konsumen yang sukses dan memiliki banyak penghasilan), thinkers (konsumen memiliki rasa puas dan nyaman), achievers (konsumen yang memiliki orientasi pada karier), believers (konsumen yang mempunyai prinsip yang kuat), strives (konsumen yang fokus pada penerimaan dari orang lain), dan makers (konsumen yang memiliki orientasi pada suatu tindakan) (Solomon, 2017).

Perilaku konsumsi $(\mathrm{Y})$ adalah suatu kegiatan konsumen dalam mengonsumsi suatu produk atau jasa yang berguna dalam memenuhi kebutuhannya (Astuti, 2016). Perilaku konsumsi diukur menggunakan 16 pernyataan yang terbagi atas tiga indikator yaitu sebelum membeli, membeli dan mengonsumsi. Kegiatan sebelum membeli yaitu berupa perilaku konsumen dalam mencari informasi produk yang akan dibeli, kegiatan membeli berupa perilaku mencari produk serta melakukan transaksi dan kegiatan mengonsumsi berupa perilaku menggunakan atau mengonsumsi produk yang telah dibelinya di toko (Sumarwan, 2015).

Pada penelitian ini digunakan analisis SEM untuk menganalisis adanya pengaruh antar variabel perceived behavioral control, variabel motivasi dan variabel gaya hidup terhadap perilaku konsumsi kopi pada masa pandemi Covid-19 ini. SEM (Structural Equation Model) adalah salah satu perangkat analisis yang dapat memberikan analisis adanya hubungan antara variabel seperti halnya variabel laten dan variabel indikator (Puspitawati, 2013). Pemilihan SEM dilakukan karena mampu memberikan penjelasan tentang pengaruh antar variabel dalam suatu model secara langsung maupun tidak langsung. SEM juga dapat memberikan penjelasan hubungan antara variabel laten dengan variabel indikator beserta besar korelasinya. Metode SEM yang digunakan dalam penelitian ini yaitu Partial Least Square atau PLS. Tujuan dari SEM-PLS adalah mengembangkan teori atau membangun teori yang mana berorientasi pada prediksi model. SEM PLS memiliki beberapa tahapan analisis yang terdiri dari evaluasi model pengukuran dan evaluasi model struktural dan pengujian hipotesis (Ghozali,
2008).

Adanya evaluasi model pengukuran berguna untuk mengetahui validasi dan reliabilitas pengukuran model pada penelitian. Pengukuran tersebut dilakukan dengan menganalisis nilai loading factor dari variabel laten terhadap indikatornya. Indikator dapat dikatakan valid jika nilai loading factor berada di atas 0,7 dan masih dapat dianggap valid hingga 0,5 (Ghozali \& Latan, 2015). Selanjutnya, dilakukan pengujian validitas dengan melihat dari AVE atau atau nilai Average Variance Extracted. Nilai AVE yang diharapkan yaitu lebih dari 0,5 yang menunjukkan bahwa lebih dari setengah konstruk dapat menjelaskan indikatornya (Hair et al., 2006). Uji reliabilitas yang terdiri dari cronbach's alpha dan composite reliability. Suatu variabel dapat dianggap reliabel jika nilai cronbach's alpha > 0,6 (Ghozali \& Latan, 2015). Berdasarkan pengujian reliabilitas, masing-masing variabel memiliki nilai cronbach's alpha $>0,6$ sehingga dapat dikatakan reliabel.

Evaluasi model struktural dilakukan dengan menganalisis nilai koefisien determinasi atau $\mathrm{R}^{2}$, nilai path coefficient, dan nilai $t$-statistics. Nilai $R^{2}$ dilihat dari konstruk variabel endogen atau variabel yang dipengaruhi. Nilai $R^{2}$ dikategorikan menjadi tiga kategori yaitu nilai $R^{2}$ 0,67 (kuat), 0,33 (moderat), dan 0,19 (lemah) (Chin, 1998). Evaluasi selanjutnya yaitu menggunakan nilai path coefficient yang dapat menjelaskan nilai hubungan antar konstruk. Nilai $t$-statistic atau $p$-values didapatkan dari hasil algoritma bootstrapping pada SmartPLS. Bootstrapping merupakan prosedur pengambilan sampel baru secara berulang sejumlah $\mathrm{N}$ sampel data dari data asal berukuran $n$ yang bertujuan untuk memungkinkan adanya data yang terdistribusi bebas (Efron \& Tibshirani, 1998). Pada penelitian ini, tingkat signifikansi yang digunakan yaitu tingkat signifikansi 5 persen sehingga nilai $t$-statistic harus bernilai $>1,96$ atau $p$-values $<\alpha=5$ persen.

Uji hipotesis yaitu pengujian yang dilakukan dengan menganalisis perbandingan nilai $t$ hitung dengan $t$ tabel berdasarkan tingkat keyakinan yang ditetapkan. Pada penelitian ini, tingkat keyakinan yang digunakan yaitu $\alpha=$ 0,05 dengan nilai $t$ tabel sebesar 1,96. Hipotesis penelitian dapat diterima jika nilai hasil pengolahan data telah memenuhi syarat nilai tersebut.

HASIL 
Tabel 1 Dimensi dan pernyataan variabel perceived behavioral control

\begin{tabular}{|c|c|c|c|}
\hline \multirow{2}{*}{ Dimensi } & \multirow{2}{*}{ Pernyataan } & \multicolumn{2}{|c|}{$\begin{array}{l}\text { Persentase } \\
\text { (\%) }\end{array}$} \\
\hline & & $\begin{array}{l}\text { Tidak } \\
\text { setuju }\end{array}$ & Setuju \\
\hline \multirow{4}{*}{$\begin{array}{l}\text { Kontrol } \\
\text { Keyakinan }\end{array}$} & $\begin{array}{l}\text { Dalam kondisi } \\
\text { pandemi Covid-19, } \\
\text { saya mempunyai } \\
\text { kesempatan untuk } \\
\text { mengonsumsi } \\
\text { produk minuman } \\
\text { kopi (PBC11) }\end{array}$ & 4,0 & 96,0 \\
\hline & $\begin{array}{l}\text { Dalam kondisi } \\
\text { pandemi Covid-19, }\end{array}$ & & \\
\hline & $\begin{array}{lr}\text { saya } & \text { sering } \\
\text { membeli produk } \\
\text { minuman kopi } \\
\text { untuk sehari-hari } \\
(\text { PBC12) }\end{array}$ & 17,0 & 83,0 \\
\hline & $\begin{array}{l}\text { Dalam kondisi } \\
\text { pandemi Covid-19, } \\
\text { penting bagi saya } \\
\text { untuk } \\
\text { mengonsumsi } \\
\text { produk minuman } \\
\text { kopi (PBC13) }\end{array}$ & 23,5 & 76,5 \\
\hline \multirow{2}{*}{$\begin{array}{l}\text { Kekuatan } \\
\text { Kepercayaan }\end{array}$} & $\begin{array}{l}\text { Dalam kondisi } \\
\text { pandemi Covid-19, } \\
\text { saya mempunyai } \\
\text { waktu yang cukup } \\
\text { melakukan } \\
\text { pembelian produk } \\
\text { minuman kopi } \\
\text { (PBC21) }\end{array}$ & 10,0 & 90,0 \\
\hline & $\begin{array}{l}\text { Dalam kondisi } \\
\text { pandemi Covid-19, } \\
\text { penting bagi saya } \\
\text { untuk } \\
\text { memperhatikan } \\
\text { dengan cermat } \\
\text { produk minuman } \\
\text { kopi (PBC22) }\end{array}$ & 7,0 & 93,0 \\
\hline
\end{tabular}

\section{Karakteristik Responden}

Hasil penelitian ini memperlihatkan bahwa responden yang mengonsumsi kopi pada masa pandemi Covid-19 ini didominasi oleh responden dengan pendidikan terakhirnya Sarjana (S1) sebanyak 98 orang (49\%) dan diikuti oleh responden dengan pendidikan terakhir Magister (S2) sebanyak 57 orang $(28,5 \%)$. Pada penelitian ini, responden dengan pekerjaan sebagai pegawai swasta yang mendominasi sebanyak 105 orang (52,5\%). Selanjutnya diikuti oleh responden dengan pekerjaan sebagai wirausaha dan ibu rumah tangga masing-masing sebanyak 33 orang $(16,5 \%)$. Hasil penelitian menunjukkan bahwa sebelum pandemi Covid-19 ini, pendapatan per bulan responden didominasi pada kategori pendapatan > Rp10.000.000,00 sebanyak 76 orang $(38 \%)$. Kondisi ini juga masih terlihat sama pada saat masa pandemi Covid-19 yang mana pendapatan per bulan responden masih didominasi pada kategori pendapatan > Rp10.000.000,00 sebanyak 59 orang (29,5\%).

\section{Perceived Behavioral Control}

Tabel 2 Dimensi dan pernyataan variabel motivasi

\begin{tabular}{|c|c|c|c|}
\hline \multirow{2}{*}{ Dimensi } & \multirow{2}{*}{ Pernyataan } & \multicolumn{2}{|c|}{$\begin{array}{c}\text { Persentase } \\
(\%)\end{array}$} \\
\hline & & $\begin{array}{l}\text { Tidak } \\
\text { setuju }\end{array}$ & Setuju \\
\hline \multirow{4}{*}{$\begin{array}{l}\text { Motivasi } \\
\text { Hedonis }\end{array}$} & $\begin{array}{lr}\text { Dalam } & \text { kondisi } \\
\text { pandemi Covid-19, } & \text { Caya tetap membeli } \\
\text { saya } & \text { produk minuman kopi } \\
\text { karena } & \text { ingin } \\
\text { mengetahui } & \text { rasa } \\
\text { produknya (MO11) }\end{array}$ & 17,0 & 83,0 \\
\hline & $\begin{array}{l}\text { Dalam kondisi } \\
\text { pandemi Covid-19, } \\
\text { saya tetap membeli } \\
\text { produk minuman kopi } \\
\text { bersama teman atau } \\
\text { keluarga atau orang } \\
\text { terdekat saya untuk } \\
\text { memperoleh } \\
\text { kesenangan (MO12) }\end{array}$ & 19,5 & 80,5 \\
\hline & $\begin{array}{l}\text { Dalam } \\
\text { pandemi Covid-19, } \\
\text { saya tetap membeli } \\
\text { produk minuman kopi } \\
\text { untuk meningkatkan } \\
\text { suasana hati (MO13) }\end{array}$ & 7,5 & 92,5 \\
\hline & $\begin{array}{l}\text { Dalam kondisi } \\
\text { pandemi Covid-19, } \\
\text { saya tetap membeli } \\
\text { produk minuman kopi } \\
\text { untuk mengikuti tren } \\
\text { terbaru (MO14) }\end{array}$ & 50,0 & 50,0 \\
\hline \multirow{3}{*}{$\begin{array}{l}\text { Motivasi } \\
\text { Utilitarian }\end{array}$} & $\begin{array}{lr}\text { Dalam } & \text { kondisi } \\
\text { pandemi } & \text { Covid-19, } \\
\text { saya merasakan } \\
\text { dengan membeli } \\
\text { produk minuman kopi } \\
\text { merupakan hal yang } \\
\text { praktis (MO21) }\end{array}$ & 12,5 & 87,5 \\
\hline & $\begin{array}{l}\text { Dalam kondisi } \\
\text { pandemi Covid-19, } \\
\text { saya merasakan harga } \\
\text { yang saya bayar untuk } \\
\text { membeli produk } \\
\text { minuman kopi tidak } \\
\text { sia-sia (MO22) }\end{array}$ & 9,0 & 91,0 \\
\hline & $\begin{array}{l}\text { Dalam kondisi } \\
\text { pandemi Covid-19, } \\
\text { produk minuman kopi } \\
\text { memberikan manfaat } \\
\text { bagi saya (MO23) }\end{array}$ & 8,0 & 92,0 \\
\hline
\end{tabular}


Tabel 3 Dimensi dan pernyataan variabel gaya hidup

\begin{tabular}{|c|c|c|c|}
\hline \multirow{2}{*}{ Dimensi } & \multirow{2}{*}{ Pernyataan } & \multicolumn{2}{|c|}{$\begin{array}{c}\text { Persentase } \\
(\%)\end{array}$} \\
\hline & & $\begin{array}{l}\text { Tidak } \\
\text { setuju }\end{array}$ & Setuju \\
\hline Innovators & $\begin{array}{lr}\text { Saya } & \text { suka } \\
\text { memegang } & \text { kendali } \\
\text { dalam } & \text { suatu } \\
\text { kelompok (INO1) }\end{array}$ & 16,5 & 83,5 \\
\hline Thinkers & $\begin{array}{l}\text { Saya tertarik } \\
\text { tentang hal yang } \\
\text { berhubungan } \\
\text { dengan mekanik, } \\
\text { seperti cara kerja } \\
\text { suatu mesin (THK1) } \\
\text { Saya suka melihat } \\
\text { toko hardware atau } \\
\text { otomotif (THK2) }\end{array}$ & 43,5 & 56,5 \\
\hline Achievers & $\begin{array}{l}\text { Saya merasa saya } \\
\text { adalah seorang } \\
\text { yang intelektual } \\
(\mathrm{ACH} 1) \\
\text { Sayaraka } \\
\text { mempelajari tentang } \\
\text { budaya, seni, atau } \\
\text { sejarah }(\mathrm{ACH} 2)\end{array}$ & 12,0 & 88,0 \\
\hline Believers & $\begin{array}{l}\text { Acara televisi saat } \\
\text { ini terlalu banyak } \\
\text { mengandung konten } \\
\text { dewasa (BEL1) }\end{array}$ & 5,5 & 94,5 \\
\hline Strives & $\begin{array}{l}\text { Saya berpakaian } \\
\text { lebih } \\
\text { dibandingkan } \\
\text { kebanyakan orang } \\
\text { (STR1) }\end{array}$ & 23,5 & 76,5 \\
\hline Makers & $\begin{array}{ll}\text { Saya suka membuat } \\
\text { barang yang dapat } \\
\text { digunakan } & \text { setiap } \\
\text { hari (MAK1) } & \\
\end{array}$ & 36,5 & 63,5 \\
\hline
\end{tabular}

Penelitian ini menunjukkan, dalam kondisi pandemi Covid-19 responden tetap membeli dan mengonsumsi produk minuman kopi. Responden mempunyai waktu yang cukup untuk melakukan pembelian dan tetap memperhatikan dengan cermat produk minuman kopi yang dikonsumsinya. Responden mengisi instrumen menggunakan lima tingkatan jawaban. Adapun untuk memperingkas jawaban, maka dilakukan klasifikasi menjadi dua yaitu setuju (cukup setuju, setuju, dan sangat setuju) dan tidak setuju (sangat tidak setuju dan tidak setuju).

\section{Motivasi}

Penelitian ini memperlihatkan, adanya pandemi Covid-19 menyebabkan sebagian besar responden merasa bosan bekerja dari rumah sehingga mereka membeli produk minuman kopi untuk meningkatkan suasana hati.
Responden merasakan dengan membeli produk minuman kopi merupakan hal yang praktis disebabkan adanya inovasi produk yang baru misalnya kopi satu liter. Responden mengisi instrumen menggunakan lima tingkatan jawaban. Adapun untuk memperingkas jawaban, maka dilakukan klasifikasi menjadi dua yaitu setuju (cukup setuju, setuju dan sangat setuju) dan tidak setuju (sangat tidak, setuju, dan tidak setuju).

\section{Gaya Hidup}

Responden memiliki gaya hidup innovators, thinkers, achievers, believers, strives dan makers. Hal ini berarti responden penelitian ini merupakan konsumen yang sukses dan memiliki banyak penghasilan, rasa puas dan nyaman, orientasi pada karir, prinsip yang kuat, fokus pada penerimaan dari orang lain dan orientasi pada suatu tindakan. Responden mengisi instrumen menggunakan lima tingkatan jawaban. Adapun untuk memperingkas jawaban, maka dilakukan klasifikasi menjadi dua yaitu setuju (cukup setuju, setuju dan sangat setuju) dan tidak setuju (sangat tidak, setuju, dan tidak setuju).

\section{Perilaku Konsumen}

Responden merasa nyaman saat membeli produk minuman kopi di coffee shop favoritnya. Kualitas kopi harus tetap terjamin dan harga harus terjangkau karena kualitas kopi dan harga terjangkau termasuk hal yang penting dalam membeli produk minuman kopi walaupun dalam kodisi pandemi Covid-19. Banyak responden yang akan langsung mengonsumsi produk minuman kopi setelah membayarnya karena ingin segera mengetahui rasa dari kopi tersebut. Responden mengisi instrumen menggunakan lima tingkatan jawaban. Adapun untuk memperingkas jawaban, maka dilakukan klasifikasi menjadi dua yaitu setuju (cukup setuju, setuju dan sangat setuju) dan tidak setuju (sangat tidak, setuju, dan tidak setuju).

\section{Hasil Uji Outer Model (Model Pengukuran)}

SmartPLS digunakan untuk mengguji outer model dengan melihat convergent validity, discriminant validity, dan composite reliability. Validitas construct dihasilkan dari nilai loading factor bagi tiap indikator construct. Berdasarkan hasil uji coba 28 indikator variabel construct, menunjukkan nilai loading factor $>0,5$. Nilai loading factor $>0,5$ menunjukkan indikator tersebut valid sebagai pengukur construct dan telah mereflesikan variabel laten. 
Tabel 4 Dimensi dan pernyataan variabel perilaku konsumsi

\begin{tabular}{|c|c|c|c|}
\hline \multirow{2}{*}{ Dimensi } & \multirow{2}{*}{ Pernyataan } & \multicolumn{2}{|c|}{ Persentase (\%) } \\
\hline & & Tidak setuju & Setuju \\
\hline \multirow{3}{*}{ Sebelum Membeli } & $\begin{array}{l}\text { Saya akan membeli produk minuman kopi di coffee shop } \\
\text { favorit walaupun dalam kondisi pandemi Covid-19 saat ini } \\
\text { (PK11) }\end{array}$ & 15,5 & 84,5 \\
\hline & $\begin{array}{l}\text { Saya akan membeli produk minuman kopi dengan merek } \\
\text { terkenal walaupun dalam kondisi pandemi Covid-19 saat ini } \\
\text { (PK12) }\end{array}$ & 35,5 & 64,5 \\
\hline & $\begin{array}{l}\text { Saya akan mencari informasi terkait produk minuman kopi } \\
\text { yang akan dibeli walaupun dalam kondisi pandemi Covid-19 } \\
\text { saat ini (PK13) }\end{array}$ & 20,5 & 79,5 \\
\hline \multirow[t]{2}{*}{ Membeli } & $\begin{array}{l}\text { Dalam kondisi pandemi Covid-19, saya melakukan pembelian } \\
\text { produk minuman kopi walaupun harus meminjam uang kepada } \\
\text { teman (PK21) }\end{array}$ & 77,5 & 22,5 \\
\hline & $\begin{array}{l}\text { Dalam kondisi pandemi Covid-19, saya membeli produk } \\
\text { minuman kopi agar tidak mengantuk pada saat bekerja (PK22) }\end{array}$ & 15,5 & 84,5 \\
\hline \multirow{3}{*}{ Mengonsumsi } & $\begin{array}{l}\text { Pekerjaan memengaruhi saya dalam mengonsumsi produk } \\
\text { minuman kopi walaupun pandemi Covid-19 (PK31) }\end{array}$ & 21,5 & 78,5 \\
\hline & $\begin{array}{l}\text { Setelah membeli produk minuman kopi, saya meminumnya di } \\
\text { tempat saya bekerja walaupun pandemi Covid-19 (PK32) }\end{array}$ & 18,5 & 81,5 \\
\hline & $\begin{array}{l}\text { Kebiasaan praktis memengaruhi saya dalam mengonsumsi } \\
\text { produk minuman kopi pandemi Covid-19 (PK33) }\end{array}$ & 16,0 & 84,0 \\
\hline
\end{tabular}

Perolehan nilai AVE secara keseluruhan memiliki nilai di atas 0,5 sehingga dapat dikatakan bahwa indikator yang digunakan telah memiliki nilai validitas yang cukup baik. Uji selanjutnya yaitu uji reliabilitas dengan menggunakan parameter cronbach's alpha dan composite reliability. Perolehan nilai uji reliabilitas menunjukkan bahwa variabel laten yang digunakan dalam penelitian ini memiliki nilai lebih dari 0,7 sehingga reliabilitas dari variabel laten yang digunakan dalam penelitian ini telah terpenuhi.

\section{Hasil Uji Inner Model (Model Struktural)}

Evaluasi model struktural dilakukan dengan menganalisis nilai koefisien determinasi atau $\mathrm{R}^{2}$, nilai path coefficient dan nilai $t$-statistics. Nilai $R^{2}$ dilihat dari konstruk variabel endogen atau variabel yang dipengaruhi. Menurut Chin (1998), nilai $R^{2}$ dikategorikan menjadi tiga kategori yaitu nilai $R^{2} \quad 0,67$ (kuat), 0,33 (moderat) dan 0,19 (lemah).

Variabel endogen yang digunakan pada penelitian ini mayoritas memiliki nilai $R^{2}$ yang masuk dalam kategori kuat. Nilai $R^{2}$ tertinggi dengan kategori kuat terdapat pada kontrol keyakinan, kekuatan kepercayaan, motivasi hedonis, motivasi utilitarian, thinkers, sebelum membeli dan mengonsumsi yaitu sebesar 0,922 $0,772,0,820,0,771,0,731,0,707$ dan 0,785 artinya variabel eksogen yang memengaruhi kontrol keyakinan, kekuatan kepercayaan, motivasi hedonis, motivasi utilitarian, thinkers, sebelum membeli dan mengonsumsi telah mewakili 92,2 persen, 77,2 persen, 82 persen, 77,1 persen, 73,1 persen, 70,7 persen dan 78,5 persen kemungkinan pembentukan kontrol keyakinan sedangkan sisanya dinyatakan oleh faktor-faktor lain di luar penelitian ini.

Nilai $\mathrm{R}^{2}$ selanjutnya adalah kategori moderat. Nilai $\mathrm{R}^{2}$ yang masuk dalam kategori moderat yaitu innovators, achievers, membeli dan perilaku konsumsi sebesar 0,460, 0,461, 0,500, dan 0,462. Artinya gaya hidup mampu menjelaskan keragaman innovators dan achievers sebesar 46 persen dan 46,1 persen, perilaku konsumsi mampu menjelaskan keragaman membeli sebesar 50 persen, dan perceived behavioral control, motivasi dan gaya hidup mampu memperlihatkan keragaman perilaku konsumsi sebesar 46,2 persen serta sisanya dinyatakan oleh variabel independent lain yang tidak terdapat di penelitian ini.

Nilai $R^{2}$ lainnya yang masuk dalam kategori lemah yaitu believers, strives dan makers. Artinya gaya hidup mampu menjelaskan keragaman believers, strives dan makers sebesar 3,1 persen, 6,1 persen dan 4 persen serta sisanya dijelaskan oleh variabel independent lain yang tidak ada di dalam model penelitian yang dirumuskan pada penelitian ini. 


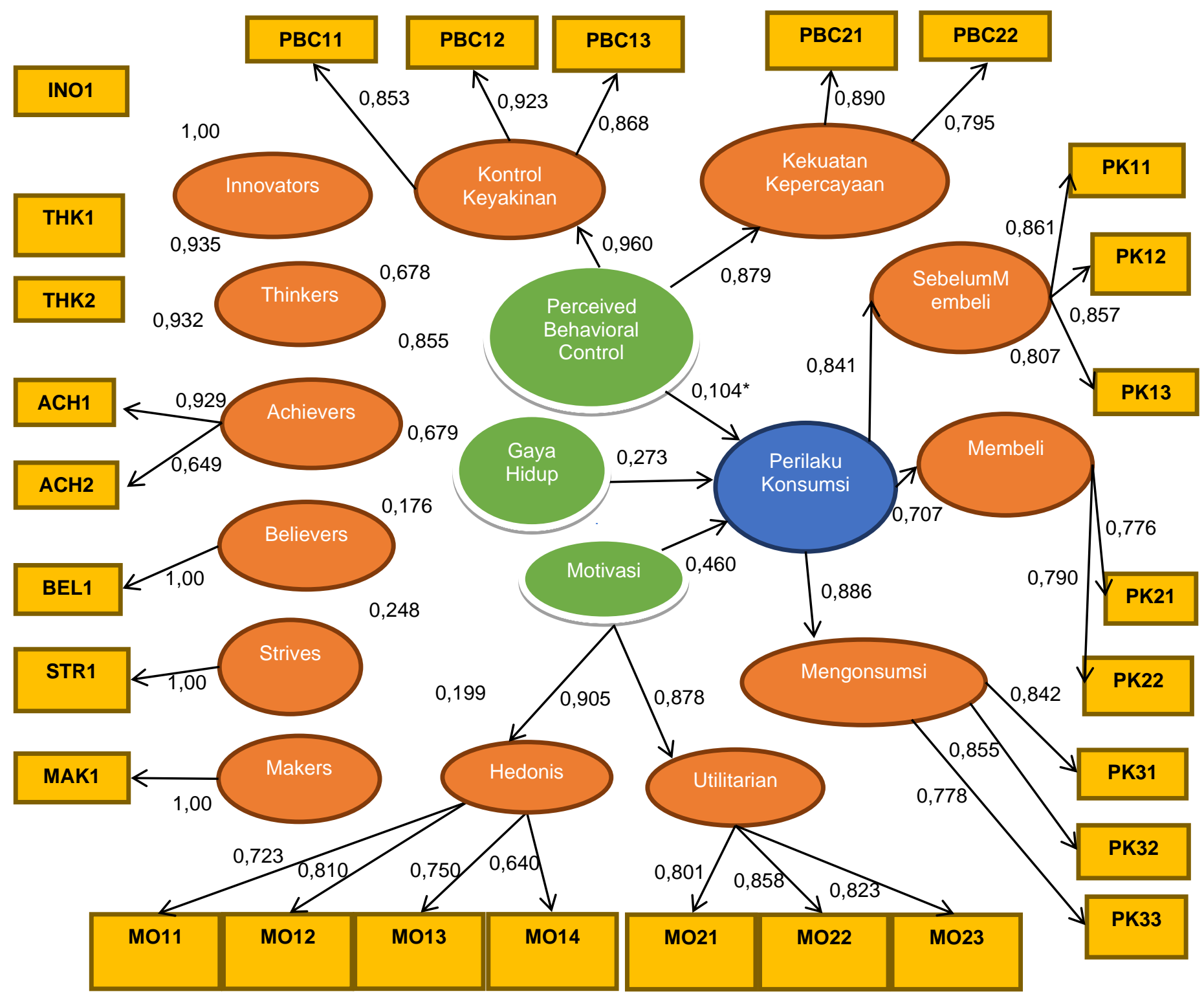

Gambar 1 Model SEM PLS dari perceived behavioral control, motivasi, dan gaya hidup berpengaruh terhadap perilaku konsumsi kopi

\section{Pengujian Hipotesis}

Keputusan hipotesis ditentukan dengan perbandingan nilai t-hitung dengan t-tabel melalui tingkat keyakinan. Pada penelitian ini, tingkat keyakinan yang digunakan yaitu $\alpha=0,05$ dengan nilai t-tabel sebesar 1,96. Pada Tabel 5 dapat diketahui bahwa pada hipotesis kedua yaitu hubungan antara motivasi dengan perilaku konsumsi juga memiliki hasil positif signifikan dengan nilai original sample 0,460 dan nilai t- hitung 6,320 sehingga hipotesis kedua dapat diterima.

Selanjutnya pada hipotesis ketiga yaitu hubungan antara gaya hidup dengan perilaku konsumsi bernilai positif signifikan yang ditunjukkan dengan nilai origin sampel sebesar 0,273 dengan nilai t-hitung 3,713 sehingga hipotesis ketiga dapat diterima.

Tabel 5 Hasil Uji Hipotesis

\begin{tabular}{lccc}
\hline \multicolumn{1}{c}{ Variabel original } & sample & T- hitung & Hipotesis \\
\hline Gaya hidup -> perilaku konsumsi & 0,273 & 3,713 & Diterima \\
Motivasi -> perilaku konsumsi & 0,460 & 6,320 & Diterima \\
Perceived behavioral Control -> perilaku konsumsi & 0,104 & 1,282 & Ditolak
\end{tabular}


Hipotesis kesatu menunjukkan bahwa hubungan antara perceived behavioral control terhadap perilaku konsumsi yang memiliki nilai tidak signifikan karena nilai t-hitung yang diperoleh lebih kecil dari nilai t-tabel yaitu 1,282 sehingga hipotesis ditolak.

\section{PEMBAHASAN}

Hasil dari uji hipotesis memperlihatkan bahwa gaya hidup memiliki pengaruh secara positif dan signifikan terhadap perilaku konsumsi sehingga hipotesis pertama dapat diterima. Hasil tersebut menjelaskan bahwa perilaku konsumsi kopi dipengaruhi oleh adanya gaya hidup walaupun saat ini konsumen berada dalam masa pandemi Covid-19. Gaya hidup setiap orang dipengaruhi oleh faktor lingkungan di kehidupan masyarakat sehari-hari atau adanya interaksi sosial (Siregar, 2015). Adanya gaya hidup memberikan pengaruh terhadap aktivitas seseorang termasuk perilakunya dalam melakukan konsumsi produk sehingga gaya hidup dapat memberikan pengaruh terhadap perilaku konsumsi seseorang secara langsung. Berdasarkan hasil penelitian, secara keseluruhan indikator pada gaya hidup memiliki nilai validitas yang cukup tinggi. Indikator tertinggi yaitu gaya hidup thinkers. Konsumen pada kelompok thinkers cenderung memilih produk kopi yang tahan lama dan mengutamakan fungsi serta nilai yang ada pada produk minuman kopi.

Hasil penelitian ini sejalan dengan penelitian terdahulu yang menemukan bahwa gaya hidup berpengaruh terhadap perilaku konsumsi (Astuti, 2016). Ini berarti bahwa gaya hidup ialah bentuk hidup seseorang yang diperlihatkankan dalam aktivitas rutin seharihari. Semakin tinggi gaya hidup seseorang maka perilaku konsumsi orang tersebut juga akan meningkat. Penelitian lain memaparkan bahwa terdapat faktor-faktor yang memengaruhi perilaku konsumsi kopi salah satunya yaitu gaya hidup karena saat ini perilaku mengonsumsi kopi sudah menjadi budaya hidup global ditambah dengan munculnya banyaknya kedai kopi yang tersebar di Indonesia sehingga masyarakat cenderung mengonsumsi kopi karena adanya gaya hidup masyarakat modern yang eksklusif dan mengutamakan prestise (Demartoto et al., 2015).

Hasil penelitian selanjutnya memperlihatkan bahwa variabel motivasi memiliki pengaruh positif signifikan terhadap perilaku konsumsi sehingga hipotesis dapat diterima. Hal tersebut juga menjelaskan bahwa pada pandemi Covid-
19 ini, konsumen tetap memiliki motivasi dalam melakukan konsumsi produk minuman kopi. Pada penelitian ini, indikator motivasi yang tertinggi yaitu motivasi utilitarian yang menjelaskan bahwa konsumen mengutamakan nilai dan tujuannya dalam mengonsumsi kopi. Konsumen cenderung mengutamakan faktor harga, manfaat kopi, dan kepraktisan yang akan diperolehnya ketika melakukan konsumsi kopi. Sementara itu, indikator kedua yaitu motivasi hedonis menjelaskan bahwa konsumen terdorong membeli kopi karena ingin memenuhi tujuan emosinya yaitu untuk meningkatkan suasana hati, mengetahui rasa kopi, dan mengikuti tren terbaru saat ini walaupun berada dalam masa pandemi Covid19.

Hasil ini didukung oleh penelitian sebelumnya yang menyatakan bahwa bentuk motivasi seperti halnya motivasi hedonis dan motivasi utilitarian dapat memengaruhi konsumen untuk melakukan suatu pembelian yang cenderung cepat karena adanya urgensi akan kebutuhan baik itu kebutuhan emosional atau kebutuhan secara fungsional (Rachma, Sholihah, \& Slamet, 2017). Penelitian lainnya juga menemukan bahwa motivasi berpengaruh terhadap perilaku konsumsi (Kurniawati et al., 2015; Praktiko \& Fatchurahman, 2012). Literatur terkait motivasi menjelaskan bahwa motivasi merupakan dorongan dari diri konsumen untuk memenuhi kebutuhan guna meraih suatu tujuan sehingga motivasi memiliki peran yang besar dalam menggerakkan konsumen untuk melakukan pembelian sehingga tujuannya dapat tercapai (Charumathi \& Varadaraj, 2019; Kim, Ozkara, \& Ozmen, 2017).

Hasil penelitian selanjutnya menyatakan bahwa variabel perceived behavioral control memiliki pengaruh tidak signifikan terhadap perilaku konsumsi. Dengan demikian, hipotesis pada penelitian ini ditolak. Hal tersebut menunjukkan bahwa perilaku konsumsi dari konsumen kopi pada masa pandemi ini bukan berdasarkan asas keyakinan atau kepercayaan namun atas dasar kebutuhan dan keinginan yang harus terpenuhi. Perceived behavioral control merupakan suatu keyakinan dari individu tentang seberapa besar kontrolnya untuk memunculkan perilaku yang akan dimunculkan sebagai akibat dari akses sumber daya dan peluang yang dibutuhkan untuk menampilkan perilaku (Juliana, 2017). Berdasarkan definisi tersebut, konsumen kopi pada penelitian ini tidak mengutamakan adanya kontrol diri dalam mengonsumsi kopi pada masa pandemi Covid19 sehingga kontrol diri tidak memiliki pengaruh 
yang signifikan dalam perilaku konsumsi kopi.

Analisis yang mendukung hasil penelitian ini menyatakan bahwa perceived behavioral control tidak memiliki pengaruh terhadap minat perilaku konsumen untuk melakukan suatu transaksi. Hal tersebut dipicu oleh adanya tingkat pendidikan yang tinggi sehingga konsumen telah memahami atau telah menjadi pakar dalam objek produk tersebut sehingga dapat memutuskan dan memiliki pengendalian yang baik dalam menggunakan suatu produk (Amalia \& Suyono, 2017). Hal tersebut dapat diartikan bahwa konsumen sudah memahami hambatan atau kemudahan karena telah mengenal baik produk tersebut sehingga kontrol perilaku bukan menjadi aspek yang diutamakan lagi dalam melakukan perilaku konsumsi. Penelitian lain yang mendukung menyatakan bahwa perceived behavioral control tidak berpengaruh positif signifikan terhadap perilaku konsumen dalam pemahaman niat membeli. Hal ini dapat disebabkan oleh adanya besarnya hambatan yang ada pada konsumen sehingga memengaruhi keinginan konsumen dalam melakukan pembelian produk (Mu'arrofah, Munir, \& Rokhim, 2020).

Berdasarkan hasil penelitian, implikasi manajerial yang dapat diberikan dikelompokkan dalam enam aspek yaitu produk, harga, promosi, proses, saluran distribusi, dan sumber daya manusia. Pada aspek produk yaitu terkait kualitas produk dan variasi menu agar konsumen tetap menyukai produk minuman kopi walaupun dalam kondisi pandemi saat ini. Pada aspek harga yaitu mempertahankan kualitas atau meningkatkan kualitas namun tetap dengan harga terjangkau karena pada masa pandemi ini masyarakat memiliki daya beli yang cukup rendah sehingga harga menjadi pertimbangan konsumen dalam melakukan pembelian. Pada aspek promosi yaitu menambah promosi di fitur aplikasi belanja online seperti Gojek, Grab, atau Shopee dan adanya promo menu bundle khusus era pandemi juga menjadi hal menarik karena dapat memberikan penawaran kepada konsumen untuk dapat membeli kopi dan set menu dengan harga terjangkau. Aspek proses berkaitan dengan proses produksi adalah para produsen minuman kopi perlu menerapkan protokol kesehatan dalam lini proses produksi dan pelayanan agar konsumen merasa aman dalam mengonsumsi kopi pada masa pandemi. Selanjutnya, pada aspek saluran distribusi adalah produsen minuman kopi dapat menambah kerja sama dengan merchant- merchant atau pihak lain untuk memperluas jangkauan agar makin menarik konsumen untuk membeli produk minuman kopi. Aspek yang terakhir yaitu sumber daya manusia yaitu menerapkan protokol kesehatan dan menerapkan aturan social distancing bagi pengunjung sehingga proses produksi dan layanan tetap aman.

Berdasarkan variabel yang berpengaruh yaitu variabel motivasi dan gaya hidup, terdapat beberapa hal yang dapat diambil sebagai masukan bagi pelaku usaha produk minuman kopi. Berdasarkan variabel motivasi, dapat diketahui bahwa responden yang merupakan konsumen produk minuman kopi cenderung merasakan bahwa kualitas produk minuman kopi yang mereka bayar sepadan dengan jumlah uang yang dikeluarkan sehingga konsumen merasa tidak rugi bila tetap mengonsumsi kopi walaupun pada masa pandemi dan konsumen membeli kopi bertujuan untuk meningkatkan suasana hati. Berdasarkan data tersebut, perusahaan disarankan dapat selalu konsisten dengan mutu produk minuman kopi agar dapat mempertahankan konsumen dan menambah varian menu agar konsumen tidak merasa jenuh.

Berdasarkan variabel gaya hidup dapat diketahui bahwa jenis konsumen produk minuman kopi berdasarkan penelitian ini cenderung pada kelompok believers, strives, makers, innovators dan thinker. Berdasarkan pengelompokkan tersebut dapat diketahui pola konsumsi konsumen produk minuman kopi yaitu konsumen yang mengutamakan inovasi produk, memiliki nilai fungsi, dikenal banyak orang, produk terkini, dan memiliki nilai praktis.

\section{SIMPULAN DAN SARAN}

Perilaku konsumen dalam mengonsumsi minuman kopi selama masa pandemi diketahui memilki perilaku yang sama seperti sebelum masa pandemi. Pada masa pandemi, konsumen tetap menggunakan preferensi merek yang biasa mereka gunakan dengan alasan bahwa kopi memiliki rasa yang berbeda satu sama lain sehingga mereka tidak mengganti preferensi merek kopi yang dikonsumsi. Temuan lain pada penelitian ini menjelaskan bahwa dalam menikmati minuman kopi, mereka akan membelinya bersama dengan teman atau orang terdekat yang memiliki selera kopi yang sama. Kopi siap saji dari kedai kopi merupakan jenis produk minuman kopi yang disukai konsumen. 
Selanjutnya, hasil uji hipotesis menunjukkan bahwa terdapat pengaruh positif signifikan antar variabel motivasi dan variabel gaya hidup terhadap perilaku konsumsi. Hasil uji hipotesis lainnya menunjukkan bahwa Variabel perceived behavioral control diketahui tidak berpengaruh siginifikan terhadap perilaku konsumsi. Berdasarkan data yang diperoleh terdapat implikasi manajerial yang dapat diterapkan bagi industri minuman kopi pada masa pandemi COVID-19 yang dikelompokkan berdasarkan enam aspek yaitu produk, harga, promosi, proses, saluran distribusi, dan sumber daya manusia.

Keterbatasan pada penelitian ini yaitu berfokus pada produk minuman kopi yang dijual di pasaran baik secara retail maupun kopi siap saji yang dibuat oleh kedai kopi. Penelitian ini juga lebih menekankan dari sudut pandang konsumen sehingga tidak melihat dari sudut pandang perusahaan produsen produk minuman kopi. Penelitian ini pun hanya berfokus pada hubungan variabel motivasi, variabel perceived behavioral control, dan variabel gaya hidup terhadap variabel perilaku konsumsi.

Saran pada penelitian ini yaitu memasukkan variabel pendekatan kepuasan konsumen, kepercayaan konsumen, ataupun loyalitas konsumen untuk mengetahui lebih jauh faktorfaktor yang memengaruhi konsumen dalam mengonsumsi kopi pada masa pandemi Covid19. Saran untuk praktisi yaitu dapat menerapkan pembelian produk minuman kopi melalui online shop karena pada masa pandemi ini banyak konsumen yang membeli produk minuman kopi melalui aplikasi atau website. Saran bagi praktisi yaitu dapat diterapkannya inovasi dan tren terbaru pada produk minuman kopi tanpa harus mengurangi kualitas kopi. Selain itu, praktisi diharapkan dapat meningkatkan promosi agar produk lebih dikenal masyarakat.

\section{DAFTAR PUSTAKA}

Ainiah, L. L. (2019). Analisis pengaruh utilitarian shopping motivation dan hedonic shopping motivation terhadap minat beli pada pusat perbelanjaan Mirota Kampus (Disertasi). Yogyakarta, ID: Universitas Teknologi Yogyakarta.

Ajzen, I. (1991). The theory of planned behavior. Organizational behavior and human decision processed, 50(2), 179211. doi:10.1016/0749-5978(91)90020-T.

Amalia, Z. N., \& Suyono, N. A. (2017). Faktor minat perilaku bertransaksi menggunakan e-commerce: Studi kasus pada mahasiswa perempuan S-1 fakultas ekonomi universitas sains Al-Qur'an Wonosobo. Jurnal Fakultas Ekonomi UNSIQ, 12(1), 123. Retrieved from http://sinta.Ildikti6.id/authors/google/59760 73 ?page $=3$.

Andi, S. J. S., Haghi, M., \& Tonekaboni, N. R. (2018). Factors affecting fast food consumption behaviors of female students in North of Iran: Application of theory of planned behavior. Caspian Journal of Helath Research, 3(3), 75-79. doi:10.29252/cjhr.3.3.75.

Astuti, R. P. F. (2016). Pengaruh status sosial ekonomi orang tua, literasi ekonomi, dan lifestyle terhadap perilaku konsumsi mahasiswa jurusan Pendidikan Ekonomi IKIP PGRI Bojonegoro. Jurnal Pendidikan Edutama, 3(2), 49-58. doi:10.30734/jpe.v3i2.36.

Basri, H., Shabri, M., \& Wahyuni, D. (2016). Pengaruh sikap, norma subjektif, perceived behavioral control dan religiusitas terhadap niat memiliki rumah berbasis pembiayaan Syariah di Kota Banda Aceh. Jurnal Megister Akuntansi, $6(2), \quad 1-11$. Retrieved from http://erepository.unsyiah.ac.id/JAA/article/view/7 733/6330.

Bhatnagar, A., \& Ghose, S. (2004). A latent class segmentation analysis of eshoppers. Journal of business research, 57(7), $\quad$ 758-767. doi:10.1016/S0148-2963(02)00357-0.

Bong, S. (2011). Pengaruh in-store stimuli terhadap impulse buying behavior konsumen Hypermarket di Jakarta. Ultima Management: Jurnal IImu Manajemen, 3(1), 31-52. doi:10.31937/manajemen.v3i1.175.

Budanti, H. S. (2017). Pengaruh lingkungan sosial dan gaya hidup terhadap perilaku konsumsi mahasiswa program studi pendidikan ekonomi FKIP UNS. Jurnal Pendidikan Bisnis dan Ekonomi, 3(2), 114. doi:10.20961/bise.v3i2.16446.

Budiarti, A, \& Puspita, E. M. (2016). Pengaruh motivasi belanja hedonis terhadap pembelian implusif melalui emosi positif pelanggan vans store Surabaya. Jurnal IImu dan Riset Manajemen, 5(5), 1-16. Retrieved from jurnalmahasiswa.stiesia.ac.id.

Chang, D. S., Chen, W. K., \& Chen, C. C. 
(2017). The role of utilitarian and hedonic values on users' continued usage and purchase intention in a social commerce environment. Journal of Economics and Management, 13(2), 193-220. Retrieved from

https://EconPapers.repec.org/RePEc:jec:jo urnl:v:13:y:2017:i:2:p:193-220.

Charumathi, D., \& Varadaraj, A. (2019). Impact of hedonic and utilitarian shopping motive on online purchase decision. Center for Studies in European Integration Working Papers Series, 11, 6-16. Retrieved from https://econpapers.repec.org/RePEc:aem: wpaper:y:2019:i:11:p:6-16.

Chin, W. W. (1998). The partial least squares approach to structural equation modeling. Methods for Business Research, 295(2), 295-336. Retrieved from https://www.researchgate.net/publication/ 311766005_The_Partial_Least_Squares Approach_t

o_Structural_Equation_Modeling.

Demartoto, A., Kartono, D. T., \& Solikatun, S. (2015). Perilaku konsumsi kopi sebagai budaya masyarakat konsumsi: Studi fenomenologi pada peminum kopi di kedai kopi Kota Semarang. Jurnal Analisa Sosiologi, 4(1), 227- 594. doi:10.20961/jas.v4i1.17410.

Efron, B., \& Tibshirani, R. J. (1998). An introduction to the bootstrap (Ed 2). New York, US: Chapman \& Hall.

Ghozali, I. (2008). Structural equation modeling metode alternatif dengan partial least square.

Semarang, ID: Badan Penerbit Universitas Diponegoro.

Ghozali, I. (2012). Aplikasi analisis multivariate dengan program IBM SPSS. Semarang, ID: Universitas Diponegoro.

Ghozali, I., \& Latan, H. (2015). Konsep, teknik, aplikasi menggunakan Smart PLS 3.0 untuk penelitian empiris. Semarang, ID: Badan Penerbit Universitas Diponegoro.

Hadiwardoyo, W. (2020). Kerugian ekonomi nasional akibat pandemi covid-19. BASKARA: Journal of Business \& Entrepreneurship, 2(2), 83-92. doi:10.24853/baskara.2.2.83-92.

Hanzaee, K., \& Irani, N. (2011). The effects of variety-seeking buying tendency and price sensitivity on utilitarian and hedonic value in apparel shopping satisfaction.
International Journal of Marketing Studies, 3(3), 89. doi:10.5539/ijms.v3n3p89.

Hartuti, E. T. K. (2018). Analisis motivasi belanja hedonic dan utilitarian pada profil konsumen dalam kota. Jurnal Pemasaran Kompetitif, 102-116. doi:10.32493/jpkpk.v1i2.857.

Husna, M., \& Lubis, P. H. (2019). Pengaruh motivasi utilitarian dan motivasi hedonis terhadap loyalitas pelanggan yang dimediasi oleh kepuasan pelanggan pada pengunjung Sport Station Banda Aceh. Jurnal Ilmiah Mahasiswa Ekonomi Manajemen, 4(1), 230-244. doi:10.24815/jimen.v4i1.9081.

Iskandar \& Rahmayanti. (2018). Pengaruh gaya hidup, kelompok teman sebaya, dan literasi ekonomi terhadap perilaku konsumsi. Jurnal IImu Manajeman dan Bisnis, 9(2), 93-104. doi:10.17509/jimb.v9i2.19749.

Juliana. (2017). Pengaruh perceived behavioral control, subjective norm, dan attitude toward behavior terhadap intensi berwirausaha antara mahasiswa laki-laki dan perempuan STIE IT\&B Medan. Jurnal IImiah

Simantek,

$$
1(4)
$$

97-

105. Retrieved from http://sciencemakarioz.org/jurnal/index.php /SIMANTEK/article/view/159/159.

Kanuk, L. L., \& Schiffman, L. G. (2010). Consumer Behavior. Ed 7. New Jersey, US: Prentice Hall.

Khalikussabir, K., Mukorobin, A., \& Wahono, B. (2020). Pengaruh religiusitas, norma subjektif, dan perceived behavioral control terhadap niat beli makanan berlabel halal: Studi pada mahasiswa FEB Universitas Islam Malang Angkatan 2016. Jurnal IImiah Riset Manajemen, 9(17). Retrieved from

http://riset.unisma.ac.id/index.php/jrm/articl e/view/8298/6838.

Kim, J. W., Ozkara, B. Y., \& Ozmen, M. (2017). Examining the effect of flow experience on online purchase: A novel approach to the flow theory based on hedonic and utilitarian value. Journal of Retailing and Consumer Services, 37(1), 119-131. doi:10.1016/j.jretconser.2017.04.001.

Kurniawati, N. I., Kohar, F., \& Syuhada, S. (2015). Pengaruh motivasi dan harga terhadap perilaku konsumsi mahasiswa Pendidikan ekonomi Angkatan 2015 
Universitas Jambi. Artikel Ilmiah. Retrieved from

https://repository.unja.ac.id/4660/1/ARTIK EL\%20ILMIAH.pdf.

Latan, H., \& Ghozali, I. (2012). Partial least square: Konsep, teknik dan aplikasi SmartPLS 2.0. Semarang, ID: Badan Penerbit Universitas Diponegoro.

Maslichah, Samudra, T. B., \& Sudaryanti, D. (2020). Pengaruh sikap, norma subjektif, dan control keperilakuan yang dipersepsikan terhadap kepatuhan wajib pajak orang pribadi di Kota Baru. Jurnal Ilmiah Riset Akuntansi, 9(1), 127-143. Retrieved from http://riset.unisma.ac.id/index.php/jra/articl e/view/6374/5254.

Mirkarimi, K, Mansourian, M, Kabir M.J., Ozouni-Davaji, R. B., Eri, M, Hosseini, S. G., Qorbani, M, Safari, O, Mehr, B., R., Noroozi, M, Charkazi, A, \& Shahnazi, H. (2016). Fast food consumption behaviors in high-school students based on the theory of planned behavior (TPB). International Journal of Pediatrics, 4(7), 2.131-2.142. doi:10.22038/ijp.2016.7011.

Mu'arrofah, A., Munir, M., \& Rokhim, A. (2020). Pengaruh sikap, norma subjektif dan persepsi kontrol perilaku terhadap niat beli produk makanan dan minuman dalam kemasan berlabel halal di supermarket kabupaten Jember. Jurnal Istiqro, 6(2), 154-169. doi:10.30739/istiqro.v6i2.570.

Nielsen. (2020). Virus corona bawa berkah bagi kopi robusta?. Retrieved from https://market.

bisnis.com/read/20200403/94/1221957/vir us-corona-bawa-berkah-bagi-kopi-robusta.

Pandowo, M. H., Pangemanan, S. S., \& Sangian, Y. G. (2020). Analyzing the factors that trigger consumers hedonic motivation in choosing local coffee shops and franchised coffee shops in manado. Jurnal EMBA: Jurnal Riset Ekonomi, Manajemen, Bisnis dan Akuntansi, 8(1), 222-231. doi:10.35794/emba.v8i1.27505.

Pangestu, S. D., \& Suryoko, S. (2016). Pengaruh gaya hidup (lifestyle) dan harga terhadap keputusan pembelian: Studi kasus pada pelanggan Peacockoffie Semarang). Jurnal Administrasi Bisnis, 5(1), 519-530. doi:10.14710/jab.v5i1.12725.

Pangestuti, E., Sunarti, S., \& Wijaya, D. N. (2018). Pengaruh gaya hidup dan motivasi terhadap keputusan pembelian: Survei pada konsumen Starbucks Kota Malang. Jurnal Administrasi Bisnis, 55(2), 68-74. Retrieved from http://administrasibisnis.studentjournal.ub. ac.id/index.php/jab/article/view/2272/2674.

Pathak, G., \& Yadav, R. (2017). Determinants of consumers' green purchase behavior in a developing nation: applying and extending the theory of planned bahavior. Ecological Economics, 134(C), 114-122. doi:10.1016/j.ecolecon.2016.12.019.

Praktiko, H., \& Fatchurahman, M. (2012). Motivasi spiritual dan budaya sekolah berpengaruh terhadap kinerja professional dan perilaku konsumsi guru ekonomi. Jurnal Pendidikan dan Pembelajaran, 19(1), 125-136. Retrieved from

http://journal.um.ac.id/index.php/pendidikandan- pembelajaran/article/view/3131/557.

Purwanto, T., \& Sukamdani, Y. (2016). Kepuasan pembelanja supermarket yang dipengaruhi motif belanja hedonic dan utilitarian mahasiswa Universitas PGRI Adi Buana Surabaya. Majalah Ekonomi, https://scholar.google.co.id/citations?user= j7aGI3QAAAAJ\&hl=id.

Puspitawati, H. (2013). Riset pemasaran dan konsumen. Bogor, ID: IPB Press.

Rachma, N., Sholihah, U. M., \& Slamet, A. R. (2017). Pengaruh shopping life style fashion involvement, hedonic shopping motivation dan sales promotion terhadap impulse buying di malang town square, dan mall olympic garden (study pada mahasiswa Fakultas Ekonomi Universitas Islam Malang). Jurnal Ilmiah Riset Manajemen, 6(1), 178-194. Retrieved from https://scholar.google.co.id/citations?user= qczJDMoAAAAJ\&hl=id.

Sahrazad, S. (2011). Gaya hidup dan motivasi berprestasi sebagai predictor terhadap prestasi akademik guru yang menjadi mahasiswa pasca sarjana Universitas Indraprasta PGRI Jakarta (Tesis). Salatiga, ID: Universitas Kristem Satya Wacana.

Siregar, E. I. S. (2015). Pengaruh gaya hidup terhadap status gizi pegawai Direktorat Politeknik Kesehatan Kementerian Kesehatan Medan (Tesis). Medan, ID: Universitas Sumatera Utara.

Solomon, M. R. (2017). Consumer behavior: buying, having, and being (Ed 12). England, UK: Pearson Education.

Statista. (2020). Coffee market price. Retrieved from

dari 
https://www.statista.com/outlook/30010000 /120/ coffee/indonesia\#market pricePrUnit.

Sumarwan, U. (2015). Perilaku konsumen: Teori dan penerapannya dalam pemasaran. Bogor, ID: Ghalia Indonesia.

Tawaqal, A. F. (2016). Ilusi uang: pengaruh sikap, norma subjektif, perceived behavioral control dan batasan anggaran terhadap willingness to pay. Jurnal of Psychology, $\quad 4(1), \quad$ 1-12. doi:10.15408/tazkiya.v4i1.10834.

Toffin. (2019). Riset toffin. Retrieved from https://toffin.id/?p=2830.

Wahyuningsih, W. (2015). Pengaruh gaya hidup hedonis, kecanduan berbelanja, keterlibatan fashion terhadap pembelian tidak terencana produk fashion global (Tesis). Yogyakarta, ID: Universitas Muhammadiyah Yogyakarta. 